\title{
Power and Voices of Authority in the Media Narrative of Malaysian Natives: Combining Corpus Linguistics and Discourse Analysis Approaches
}

\author{
HABIBAH ISMAIL \\ Fakulti Pengajian Bahasa Utama, \\ Universiti Sains Islam Malaysia \\ habibah.ismail@usim.edu.my \\ HAZLEENA BAHARUN \\ Fakulti Pengajian Bahasa Utama, \\ Universiti Sains Islam Malaysia \\ HAZLINA ABDULLAH \\ Fakulti Pengajian Bahasa Utama, \\ Universiti Sains Islam Malaysia \\ SITI NORZAIMALINA ABD MAJID \\ Pusat Bahasa Moden dan Sains Kemanusiaan, \\ Universiti Malaysia Pahang
}

\begin{abstract}
Orang Asli is a group of indigenous people who live according to a set of lifestyle and belief system and speak the native language. Previous studies have found that the Orang Asli are mostly depicted in the news media as backwards and dependent on others (Marlina Jamal \& Shakila Abdul Manan, 2016). Such stereotypical depiction is shared with other research undertaken in various countries, particularly those in Canada or Australia. While many of these studies analysed findings from the media and communication or socio-cultural perspectives, the present study examines the representation of Orang Asli in Malaysian news/media by focusing on the use of language, i.e. linguistic viewpoint. The examination undertaken in this study focuses on headlines and lead paragraphs of one of the most influential English language newspapers in Malaysia. This study demonstrates the synergy of two methodological approaches in linguistics namely critical discourse analysis and corpus linguistics. Our main findings show how Orang Asli is consistently depicted around stereotypical news narratives such as issues of land rights and other resources. We also found that the voices of Orang Asli leaders are overshadowed by other authorities such as the state government. Thus, this study contributes to shed light on the linguistics resources and language patterns used to portray the Orang Asli in Malaysian newspapers.
\end{abstract}

Keywords: Orang Asli; news discourse; corpus linguistics; critical discourse analysis; indigenous people

\section{INTRODUCTION}

Minority groups like the native people or the indigenous people face some level of biasness in the media. This, according to van Dijk (1993) is because media has the ability to shape and to an extent, create certain perceptions and ideologies within a society. Previous studies have shown that indigenous people are often misrepresented (Fleras and Kunz, 2001), or underrepresented in the news media (Browne, Gleeson, Adams, Atkinson, \& Hayes, 2018; Drache, Fletcher, \& Voss, 2016, Meadows, 2001), with their voices are either silenced or overpowered by other authorities (Mesikämmen, 2016). Browne et al. (2018) who analysed the extent and nature of coverage of Aboriginal and Torres Strait Islander nutrition issues in major Australian newspaper over a 20-year period (1996-2015) found that the coverage of those investigated did not reflect the diversity and strengths of Australia's First Peoples. Evidence of underrepresentation of the indigenous people was also highlighted by Drache, Fletcher \& Voss (2016) who analysed articles on issues relevant to indigenous individuals and communities in 
Canada from 2014 to 2015. They found a pattern of persistent under-representation of their subjects of investigation in Canada's mainstream media particularly those that dealt with murdered and missing indigenous women. Another Canadian-based study also noted that newsgathering routines and the 'unspoken' mainstream bias are also pronounced in the newsroom resulting in inequitable media representations of minorities, including the indigenous people (Clark, 2017). A past study also found that indigenous voices were underrepresented in Australian and Canadian news coverage (Meadows, 2001). However, positive changes were later noted by other studies in Australia which shows selected indigenous leaders' voices were projected in the mainstream news media (Burrows, 2004; McCallum et al., 2012). Despite these progress, a recent study noted that in terms of focus, the media still "shows much of the information and views reported in the news stories about the Intervention came from government representatives" (Mesikämmen, 2016, p. 12) instead of the indigenous people themselves. Similar findings were also reported in other parts of the world, including Asian countries like Malaysia where studies found that the news stories about the Orang Asli revolve around statements given by government and that this government is often depicted in a positive light (e.g. Alagappar, David and Ramayan 2010; Marlina Jamal and Shakila Abdul Manan 2016).

In 2015, it was estimated that the number of Orang Asli is comprised of 13.8\% from the 31 million people in Malaysia (International Work Group for Indigenous Affairs, 2018). Malaysian Orang Asli are divided into tribal groups such as the Semang, Senoi and Proto Malay and they are well known to abide to certain lifestyle and cultural traditions (Tarmiji, Masami, $\&$ Norhasimah, 2013). Despite the numerous cultural traditions, and a number of advances within the Orang Asli communities, the prominent identities of these Orang Asli are depicted quite differently by the media since they were portrayed in a stereotypical and negative way (cf. Marlina Jamal and Shakila Abdul Manan 2016). We wish to argue that there is a need to examine how indigenous people are represented by the Malaysian media as related studies are rather limited. This leads to the aim of the present study. The aim of this study is twofold. Firstly, we are interested to investigate the portrayals of Orang Asli especially how authoritative voices are represented in a Malaysian English language newspaper. Secondly, we also wish to demonstrate the use of corpus-assisted discourse analysis and how this linguistic method can help to tease out interesting language patterns. Since minority groups and indigenous people are seen as under or misrepresented in the news/media, it is also one of the aims of this study to unmask the many portrayals of Orang Asli through the use of linguistic analysis to further contribute to the existing literature.

\section{REPRESENTATION OF THE NATIVE PEOPLE IN MALAYSIA AND BEYOND}

In Malaysia, studies related to the Orang Asli are commonly on land rights, the lifestyle of Orang Asli, or the community that requires constant assistance from the government. This can be seen in a study by Mustafa (1994) where he found that the Orang Asli was usually mentioned in the news when they were in some ways connected to the mainstream society or politicians, i.e. authorities. Often, this was to spark readers' interest or to show news worthiness. There was little effort to involve Orang Asli in serious issues and their visibility in the media showed superficial image that Malaysia consisted of diverse culture (Mustafa, 1994).

Alagappar, David and Ramayan (2010) compared Orang Asli's representation in the media between two different years, 1992 and 2008 using agenda setting framework. From the study, it was found that after sixteen years, the voice of Orang Asli was still not heard. Although the number of articles on Orang Asli increased from 48 news in 1992 to 81 news in 2008, the media continues to portray Orang Asli as a community that was underprivileged and in need 
of continuous aid. The problems and challenges reported in 1992 were not critically addressed and were still found to exist in 2008. In a similar vein, Loh (2011) highlighted that between January to June 2010, the The Star and Malaysian Insider online news websites focused only on land and religious issues when discussing Orang Asli. In a more recent study by Marlina Jamal and Shakila Abdul Manan (2016), the mainstream media still depicts Orang Asli as primitive, traditional, uncivilized, backward and dependent. They reported that the Orang Asli community is portrayed as an ignorant community still in need of help (Marlina Jamal \& Shakila Abdul Manan, 2016). On the other hand, the then ruling political party was projected as bringing positive changes with government organisations such as JAKOA continuously aiding the community. Despite studies related to Orang Asli have moved from ethnographical discussions; the descriptions, culture, lifestyle of the Orang Asli, to more significant or serious issues such as indigenous rights, government policy imposed to this community, political representation and community survival, the representation/portrayal of the Orang Asli communities is still the same; primitive, traditional, uncivilized, backward and dependent. These stereotypical images of Orang Asli clearly have not changed from the 1990s (see Mustafa, 1994), and we argue that their portrayal on the news has created a static social identity of the Orang Asli community.

\section{MEDIA, POWER AND IDEOLOGICAL CONSTRUCTION}

The role of news media in constructing knowledge about minority groups like the indigenous people in Australia (Mesikämmen, 2016) has shown immense importance in research. By investigating discourse, the role that media plays can be examined to understand how a type of social practice establishes or is established by certain social phenomena (Carvalho, 2008). According to scholars, while much of the media is based on social context, it also has the power to shape issues, agendas and public discourses that in turn, creates the sense of news making (Fairclough, 1995; Richardson, 2007). The curation of news mostly involves what is known as 'news values', i.e. certain criteria that determine something to be newsworthy. Linguists have often investigated language use in the media and have found that language is an important tool to not only express, embed, but also construe news values (Bednarek \& Caple, 2014). Hence, the media has much influence on what is talked about, and more importantly, how it is talked about. This type of power also gives media a significant role in shaping society's perceptions and beliefs on a certain issue, thus pointing to news values as ideological (Bednarek \& Caple, 2014).

\section{DATA AND CORPUS-ASSISTED DISCOURSE ANALYSIS APPROACH}

Data were collected from The Star (online) newspaper (henceforth TS), which is one of the most trusted English language newspapers in Malaysia (Newman, Fletcher, Kalogeropoulos, Levy, \& Nielsen, 2018). TS is also considered as a major English language newspaper at the national level which is indicated by the wide readership numbers (Su, 2017). TS newspapers have been examined in a number of studies such as Mustafa (1994), Loh (2011) and, Marlina Jamal and Shakila Abdul Manan (2016). However, in all these studies, the data collection is either too small (e.g. 12 news article by Marlina Jamal and Shakila Abdul Manan, 2016) or the observed period is too short (e.g. Mustafa monitored and examined newspapers published in August 1993 and April 1994, approximately 2 months). On the other hand, data for this study, or the Orang Asli corpus (henceforth OA corpus), were collected between February 2003 to February 2019 (approximately 16-years' worth of data). Only headlines and lead paragraphs were gathered since these two elements are coined as 'nucleus' which summarises the main 
ideas of the news stories or contain the core information about the stories (Feez, Iedema, \& White, 2010).

Many linguistic studies on news or media discourse have used critical discourse analysis (CDA) as the main analytical approach. The popularity of CDA in analysing news discourse is partly due to its function to illuminate ideologies and power (Renugah \& Tan, 2015). For example, representation of actors in football news (Nadharatunnaim \& Sureinderpal, 2019) or representation of governments in business news stories (Duc, 2013). Likewise, CDA is commonly used to examine language use to portray minority groups like indigenous people of Australia (Mesikämmen, 2016), Tionghoa communities in Indonesia (Thaniago, 2017), and Orang Asli in Malaysia (Marlina Jamal \& Shakila Abdul Manan, 2016). There are also studies about indigenous people which do not explicitly mention the method used but based on the analysis and discussion, we could surmise that content analysis or discourse analysis was used in these studies (e.g. Alagappar, David, \& Ramayan, 2010; Mustafa, 1994; Pierro et al., 2013). Despite its popularity, critical discourse analysis has been subjected to a number of criticisms, and one of them is due to possible cherry picking of texts which are usually small in number (Widdowson, 2004).

In order to overcome this weakness, the use of CDA and corpus linguistics approaches together has been proposed by a number of linguists (e.g. Baker et al., 2008; Hardt-Mautner, 1995; Orpin, 2005). This combination synergises the best elements of both approaches and has given rise to many studies which cover different fields and discourses such as academic discourse, social media discourse, and news discourse (Iqbal, Danish, \& Iqbal, 2014; Lukac, 2011; Marchi \& Taylor, 2009; Martins, 2009; Mulderrig, 2012; Prentice \& Hardie, 2009; Salama, 2011). The combination of these two approaches is also known as corpus-assisted critical discourse analysis. The comprehensiveness of the approach has motivated us to adopt the corpus-assisted critical discourse analysis as our main method of analysis.

With regards to the CDA approach used, we position the analysis in this paper as small ' $c$ ' critical discourse analysis, which is contrasted with the big ' $\mathrm{C}$ ' by the three big proponents of CDA namely Fairclough, van Dijk and/or Wodak (Bednarek, 2014). Instead of following the framework from the three big schools, we focus our analysis on the critical analysis of words or language patterns found in the concordances or collocations. Our small 'c' approach is based on the assumption that language and discourse are interconnected since language can construct a particular way a certain discourse is presented in the social world (Fairclough, 1995; Wodak \& Meyer, 2009). This study used corpus-assisted critical discourse analysis to analyse the Orang Asli's representation in the Malaysian media to gain a better understanding of the Orang Asli's news discourse. It was done by examining the types of language pattern which indicate the ideology of power or powerlessness.

Two main techniques from corpus linguistics approaches namely key word analysis and collocational analysis were adopted. These analyses were undertaken using KeyWord and Concord functions in WordSmith Tool version 6.0 (Scott, 2014a). For the analysis, two corpora were compared against each other to generate a list of key words. A key word is a word "whose frequency is unusually high in comparison with some norm" (Scott, 2014b, pp. 219, 231). The key words with unusually high frequency are called positive key words, while key words with unusually low frequency in comparison with the frequency in the reference corpus, are called negative keywords. In this study, the OA corpus is compared against a general news corpus or also known as a reference corpus. The OA corpus contains approximately 68000 words while the reference corpus is around 733000 words, which are suitable sizes for the analysis of key words.

Selected key words were further analysed using collocational analysis which generated collocates. Collocations are "co-occurring" words that appear around a target word, so for example the collocates of letter are stamp and post (Scott, 2014b, p. 171). The phrase 
'significant collocates' was used in this study to refer to any collocates of the target word that has a specific mutual information (MI) value, deemed to be statistically significant, that is similar or higher than 3 (Hunston, 2002). For practicality, we used the term 'news stories' to refer to headlines and lead paragraphs of the news articles.

\section{FINDINGS \& DISCUSSION: KEY WORDS ANALYSIS}

The key word analysis generated 53 negative keywords and 319 positive key words which amounted to a total of 372 key words as shown in Figure 1. These key words were further examined to pinpoint the focus of analysis and the process is shown in Figure 1.

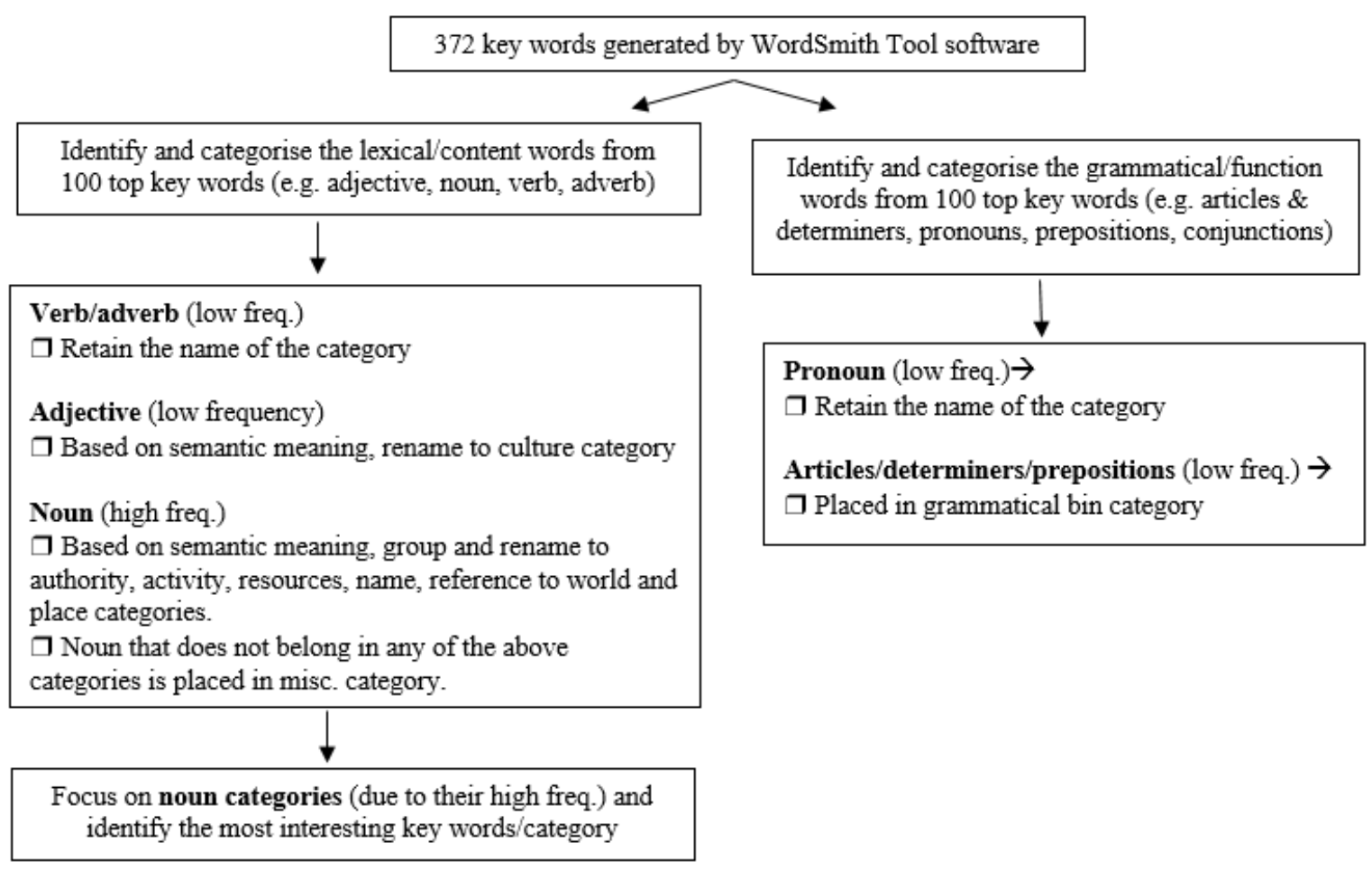

FIGURE 1. Research procedure in selecting and categorising key words

Following the key word analysis, a comparison of positive keywords and negative keywords is shown in Table 1, with key words grouped into different semantic categories. Table 1 shows an overview of positive and negative key words. Due to limited space, Table 1 only shows the negative key words and the top 100 positive key words, but some words are deleted like numbers and days (e.g. Monday). Following each key word, two numbers are shown in brackets; the first number refers to the raw frequency of occurrences and the second being the normalised frequency over 10, 000 words of those key words. Asterisk (*) is used in Table 1 to indicate that a word may belong to more than one lexical or thematic category. 
TABLE 1. Categories of keywords (Overview)

\begin{tabular}{|c|c|c|c|}
\hline Category & Sub-categories & Positive key words (Top 100) & Negative key words \\
\hline Authority & $\begin{array}{l}\text { Other } \\
\text { Orang Asli (OA) }\end{array}$ & $\begin{array}{l}\text { Department (122/18); Forestry (47/7); } \\
\text { JAKOA (36/5); State }(167 / 24) \text {; Suhakam } \\
\text { (44/6); Government }(215 / 31) \\
\text { Batin (19/3) }\end{array}$ & $\begin{array}{l}\text { President (6/0); States }(5 / 0) \\
\text { Capital }(4 / 0)\end{array}$ \\
\hline Activity & & $\begin{array}{l}\text { Blockade (89/13); Logging }(79 / 12) \text {; } \\
\text { Missing (88/13); Living }(73 / 11) ; \\
\text { Development }(137 / 20) ; \text { Rights }(91 / 13) ; \\
\text { Blockades }(26 / 4) ; \text { Landslide }(26 / 4) ; \\
\text { Clearing }(21 / 3) ;{ }^{*} \text { Build }(41 / 6)\end{array}$ & $\begin{array}{l}\text { Trade }(4 / 0) ; \text { Financial }(4 / 0) \\
\text { Industry }(5 / 0) ; \text { Business }(4 / 0) \\
\text { Deal }(6 / 0) ; \text { Technology }(7 / 1)\end{array}$ \\
\hline Resources & & $\begin{array}{l}\text { Land }(307 / 45) \text {; Forest }(110 / 16) \text {; Water } \\
(95 / 14)\end{array}$ & Oil $(22 / 3)$ \\
\hline Place & Proper noun & $\begin{array}{l}\text { Musang (197/29); Gua (193/28); Kelantan } \\
\text { (181/27); Perak (150/22); Pos (99/14); } \\
\text { Sungai (115/17); Cameron (75/11); } \\
\text { Highlands (76/11); Pahang (98/14); Baru } \\
\text { (125/18); Tohoi (45/7); Sk (44/6); Hulu } \\
\text { (38/6); Tapah (32/5); Reserve (68/10); } \\
\text { Kota (77/11); Gerik (29/4); Rompin (26/4); } \\
\text { Balah (23/3); Ulu (31/5); Gopeng (25/4); } \\
\text { Belum (25/4); Temerloh (21/3); Bulkit } \\
\text { (52/8); Dam (21/3); Chini (18/3); Pekan } \\
\text { (23/3); Gombak (21/3); Raub (20/3); Ruil } \\
\text { (16/2); Johor (105/15); Tasik (20/3); Ipoh } \\
\text { (69/10); Simpang (35/5) } \\
\text { Kampung (247/36); Village (150/22); } \\
\text { Villages (96/14); Jungle (49/7); Settlement } \\
\text { (90/13); Settlements (36/5); Court } \\
\text { (101/15); School (150/22); Homes (66/10); } \\
\text { Houses (44/6); Rural (45/7); River (31/5) }\end{array}$ & $\begin{array}{l}\text { Lumpur (120/18); Kuala } \\
(178 / 26) ; \text { Malaysia }(129 / 19) ; \\
\text { Penang }(13 / 2)\end{array}$ \\
\hline \multirow[t]{2}{*}{$\begin{array}{l}\text { Group of } \\
\text { people }\end{array}$} & Referring to $\mathrm{OA}$ & $\begin{array}{l}\text { Orang (2574/ } 377) ; \text { Asli }(2558 / 375) ; \\
\text { indigenous }(95 / 14) ; \text { *native }(39 / 6) ; \\
\text { Community (334/49); Children }(253 / 37) ; \\
\text { Villagers }(106 / 16) ; \text { Temuan (39/6); Pupils } \\
(65 / 10) \text { Tribe }(38 / 6) ; \text { Kids }(60 / 9) ; \text { Families } \\
\text { (53/8); Temiar }(31 / 5) ; \text { Communities (44/6); } \\
\text { Peoples (24/4); Semai (19/3) }\end{array}$ & \\
\hline & $\begin{array}{c}\text { Other than OA } \\
\text { Both }\end{array}$ & Loggers $(38 / 6)$; Volunteers $(28 / 4)$ & $\begin{array}{l}\text { Chinese (7/1) } \\
\text { Malaysian (35/5); Public (10/1) }\end{array}$ \\
\hline Name & & $\operatorname{Bah}(17 / 2)$ & - \\
\hline $\begin{array}{l}\text { Reference to } \\
\text { the world }\end{array}$ & & - & $\begin{array}{l}\text { World (31/5); Global }(7 / 1) ; \\
\text { International }(18 / 3) \text {; Foreign } \\
(4 / 0) ; \text { Asia }(12 / 2)\end{array}$ \\
\hline Misc. & & Livelihood (20/3); Seven (65/10) & $\begin{array}{l}\text { Bhd }(23 / 2) ; \text { Year }(106 / 16) ; \\
\text { Higher }(7 / 1) \text {; Second }(8 / 1) ; \\
\text { New }(103 / 15) \text {; Expected }(8 / 1) \text {; } \\
\text { News }(12 / 2) ; \text { Third }(6 / 0) ; \text { Sdn } \\
(8 / 1) \text {; United }(11 / 2) ; \text { Top } \\
(18 / 3) \text {; Target }(7 / 1) ; \text { Former } \\
(10 / 1) ; \text { Next }(23 / 3) ; \text { Media } \\
(12 / 2) ; \text { According }(12 / 2)\end{array}$ \\
\hline
\end{tabular}

Based on the analysis, we identified eight categories related to nouns. They are authority, activity, resources, place, group of people, name, reference to the world and miscellaneous categories.

The activity category which includes words such as blockade, logging, and rights and the resources category with words such as land, forest and water, denote news stories about 
customary land and other resources of the Orang Asli. This resonates with what was mentioned in a study conducted by Tarmiji, Masami and Norhasimah (2013) that the Orang Asli "struggle for recognition of their identities, their ways of life and their right to traditional lands, territories and natural resources" (p.76). Quite rarely though, are the Orang Asli connected to news stories about trade, business or technology as indicated by the negative key words of the activity category. This category is somehow related to the reference to the world category, where words such as global, international and Asia are unusually underrepresented in the news stories about Orang Asli. This is much anticipated and somehow portrays their current economic priority/activity and state. Similarly, it is given that place and group of people categories function as background information which identify the home and the ethnic of Orang Asli people. Only one word, Bah, appears in the name category. Bah appears in 17 instances as part of a proper name to 5 different people of indigenous background (e.g. Dr Bah Piyan Tan, Bah Tony) and 1 instance as part of village name (Kampung Air Bah Sawa).

As the main aim of this study was to investigate the portrayals of Orang Asli in the news media, we will focus our discussion on the authority category as we are interested to examine how power is construed and how ideologies are connected to them. This focus is guided by the findings of previous studies (e.g. Messkimen, 2016 and Mustafa, 1994) which found that mainstream media failure to acknowledge the voices of indigenous people led to bias representation. The issue of power and ideology is inherent in the discussion about OA discourse since we agree with the argument by Messkimen (2016) that by limiting the voices of the indigenous people, we are also limiting the discursive power of the indigenous people in general, thus limiting our understanding about them. At the same time, we might inadvertently impose, the mainstream ideologies onto this minority group.

Words shown in the authority category especially the positive key words show the kind of people in power or institutions who/that are frequently connected or involved when talking about Orang Asli. The positive key words mostly represent the government or extended bodies of the government realised through words such as SUHAKAM (Suruhanjaya Hak Asasi Manusia), JAKOA (Jabatan Kemajuan Orang Asli), state and department. The fact that key words related to authorities are considered significant in news stories about the Orang Asli, are in line with the finding of a past study that found "the news reports reveal the identity of the many governmental organisations" (Marlina Jamal \& Shakila Abdul Manan, 2016) and their role in the Orang Asli community. Further discussions about the authority category are presented in the next section.

\section{THE AUTHORITIES IN NEWS STORIES ABOUT ORANG ASLI: CORPUS-ASSISTED DISCOURSE ANALYSIS}

The seven key words related to authorities (see Table 1), arranged from the least to the most frequently occurring key words are Batin (freq. 19; rank: 94), JAKOA (freq. 36; rank 36), SUHAKAM (freq. 44; rank 39), forestry (freq. 47; rank 33), department (freq. 122; rank 28), state (freq. 167; rank: 38), and government (freq. 215; rank 61). The only mention of Orang Asli as an authority figure is realised through the word Batin i.e. Tok Batin, which is the title of the leader of Orang Asli. It is quite interesting to see that despite being the sole authoritative figure for the Orang Asli, Tok Batin appears to be mentioned the least and has the lowest rank among all the other key words in this category. It can also be seen that the key word department is ranked at number 28 of all the significant positive key words and government is the most frequently mentioned authoritative figure (freq. 215). For the purpose of examining these keywords in the authority category, we have examined all seven key words as they are used 
in context by analysing collocates and concordance lines. Whenever seemingly appropriate, we have also categorised the collocates to ascertain any interesting emerging patterns.

\section{BATIN}

There are only two significant collocates of the word Batin which are threatened and village. The high frequency of the term threatened being associated with Tok Batin, might be due to news stories covering the Cameron Highland by-election in early 2019, which saw the nomination of the first Orang Asli as one of the candidates. The prominence of political elements was mentioned by Marlina Jamal and Shakila Abdul Manan (2016, p. 49, our insertion): "[p]olitics is a recurring theme as several news reports involving the community are often politicised to favour the ruling party".

Since the collocational analysis did not reveal much, we looked at the dispersion of the term from 2003 to 2019 and its frequency of occurrences. Altogether there are nineteen instances of the term Tok Batin in our corpus where most of them were recorded in 2019, due to the above-mentioned by-election, with only five instances appearing in 2009, 2010 and 2013. Selected lines from the concordances are presented in Table 2 below to illustrate how Tok Batin is represented in the news stories.

TABLE 2. Concordance lines of news stories about Tok Batin

\begin{tabular}{|c|c|c|}
\hline & $2013,2010 \& 2009$ & 2019 \\
\hline 17 Feb 2013 & $\begin{array}{l}\text { 1....Kampung Air Banum's village head Tok Batin } \\
\text { Abu's heart aches each time a lorry passe }\end{array}$ & $\begin{array}{l}\text { 6. MCA Youth has urged the Tok Batin (orang asli village } \\
\text { headmen) who were all }\end{array}$ \\
\hline 24 Jul 2010 & $\begin{array}{l}\text { 2. A TOTAL of } 176 \text { orang asli Tok Batin } \\
\text { (headman) in Perak would receive a better }\end{array}$ & $\begin{array}{l}\text { 7. Orang asli village heads or Tok Batin will not be denied } \\
\text { their salaries even if }\end{array}$ \\
\hline 24 Jul 2010 & $\begin{array}{l}\text { 3. Orang asli Tok Batin to get higher allowance A } \\
\text { TOTAL of } 176 \text { or }\end{array}$ & 8. Muhyiddin: We did not force tok batin to read speech \\
\hline 15 Apr 2009 & $\begin{array}{l}\text { 4. At the break of dawn, Tok Batin Garus Badak } \\
\text { and fellow orang asli village }\end{array}$ & $\begin{array}{l}\text { 9. ... denies allegations that a village head (tok batin) was } \\
\text { forced to read out the text of a spe }\end{array}$ \\
\hline 6 Jun 2009 & $\begin{array}{l}\text { 5. KAMPUNG Rasau Ulu tok batin (community } \\
\text { leader) Erak Sarik has fond memories }\end{array}$ & $\begin{array}{l}\text { 10.An orang asli village head (tok batin) claimed he was } \\
\text { asked to read out a speech... }\end{array}$ \\
\hline
\end{tabular}

While there is a good number of the term Tok Batin, the presence of it is not associated with power. First, the term only appears once or twice a year before 2019's by-election. So, it can be deduced that the representation of Tok Batin as the head of Orang Asli is not well portrayed. Second, when they are mentioned in the news report, they are usually represented as powerless (did not force. See Table 2, line number 8), emotional (fond memories, heart aches. See Table 2, lines number 1 and 5) and positioned at the receiving end of things (e.g. salary. See lines number 3 and 7).

Despite the numerous mentions of Tok Batin in 2019, the treatment they received did not change much compared to the previous years. They are still at the receiving end of things as found in line 7 (Table 2). The voice of Tok Batin is also replaced by the voice of others e.g. MCA youth and Muhyiddin. This, once more conceals their visibility in the media and undermines their involvement in serious issues of the country (Alagappar et al., 2010). Thus, we can conclude that the Tok Batin's voice or concern does not carry much weight when dealing with people outside his community. And as mentioned before, the power and significance of Tok Batin are overshadowed by the other six authorities in terms of number of instances and rank. 
Under the authority category, JAKOA is one of the positive key words which is an acronym that stands for Jabatan Kemajuan Orang Asli or Department of Orang Asli Development. It is responsible for the development and wellbeing of the Orang Asli communities in the country. From the corpus, there are 36 instances of JAKOA being mentioned and 6 significant collocates namely: director, general, department, datuk, development and says. A message that is clear from these collocates is that the main voice of JAKOA is heard from the director general of the department. It has been reported in a previous study that many times, the government representatives are the main agents in news stories about native people (Mesikämmen, 2016). To illustrate this, we further analysed the texts by examining interesting contexts from the concordance lines.

TABLE 3. Selected concordance lines of news stories about JAKOA

\begin{tabular}{ll}
\hline 1 & nt THE Perak Orang Asli Development Department (Jakoa) will be recounting the number of trees owned \\
2 & reements THE Orang Asli Development Department (Jakoa) will set up specific guidelines for farmers $r$ \\
3 & TRAJAYA: The Orang Asli Development Department (Jakoa) will soon have a director-general from the co \\
4 & eri Dr Ahmad Zahid Hamidi. 6 Oct 2015 | 7:00 AM Jakoa wants RM50mil to build houses IPOH: The Depart \\
5 & d reject modern medicine. 25 Nov 2015 | 7:00 AM Jakoa to check claims of 200 orang asli deaths PETAL \\
6 & says the indigenoues people or Orang Asli wants JAKOA to be closed down for not consulting with the \\
7 & ment and the Orang Asli Development Department (Jakoa) to address absenteeism among them. 10 Nov 201 \\
8 & ward to busy days ahead. 25 Aug 2011| 12:00 AM Jakoa targets 500 orang asli entrepreneurs by 2015 T \\
9 & JAYA: The Department of Orang Asli Development (Jakoa) spoke out against claims that it mistreated t \\
10 & located lands. 17 Jun 2015 | 6:45 PM Close down JAKOA, says NGo JOAS says the indigenoues people or \\
11 & rang asli community there. 2 Jun 2015 | 7:00 AM Jakoa meets orang asli and farmers to draw up proper \\
12 & NG JAYA: The Orang Asli Development Department (Jakoa) has refuted former prime minister Datuk Seri \\
13 & NG JAYA: The Orang Asli Development Department (Jakoa) has assured that orang asli in Gua Musang, Ke \\
14 & AYA: The Depart-ment of Orang Asli Development (Jakoa) has denied claims that the orang asli familie \\
15 & are that of his daughter. 12 Oct 2015 | 7:00 AM Jakoa denies mistreating relatives of missing pupils
\end{tabular}

Based on our examination, two words pique our interest, namely wants and will which appear together with JAKOA as shown in Table 3 line 1 to line 4. The use of these words may possibly indicate JAKOA's intentions in relation to Orang Asli matters. The use of will is illustrated in the excerpt below.

Lead para.: The Orang Asli Development Department (JAKOA) will set up specific guidelines for farmers renting land from orang asli in Cameron Highlands. 2 Jun 2015

In this excerpt, the interest of the Orang Asli is considerably protected when specific guidelines and rental agreements became JAKOA's focus. It can be said that JAKOA, as the authority, functions as an entity that is responsible for the welfare and wellbeing of the Orang Asli communities in the country. JAKOA acts as the intermediary between the Orang Asli communities and other parties that have interests in the Orang Asli.

Despite not having the exclusive / sole power to decide on important matters, JAKOA still holds some degree of control over issues involving Orang Asli. For instance, JAKOA is 
greatly involved in matters involving the welfare of the Orang Asli, as seen in line 13 in Table 3, and in the excerpt below:

Lead.: PETALING JAYA: The Orang Asli Development Department (JAKOA) has assured that orang asli in Gua Musang, Kelantan, will enjoy treated water again by the first week of next month.

17 Apr 2015

In the second excerpt above, the upper hand that JAKOA has is exhibited differently compared to the one in the first excerpt, albeit with a similar function which is to ensure the wellbeing of the Orang Asli. Our examination of the key word JAKOA has shown the different roles of the department and the power exercised over the Orang Asli as represented in the news. In the next section, we will discuss three key words that stand for different government and non-government entities.

\section{SUHAKAM, FORESTRY \& DEPARTMENT}

The key words SUHAKAM, forestry and department are discussed together as they are interrelated and many times, they appear in the same news stories i.e. tied to similar events. As mentioned before, there are 44 instances of the term SUHAKAM in our data. The significant collocates of SUHAKAM are commission, rights, and Malaysia. The collocational analyses have revealed very little, due to the span limit of 4 words to the right and left of the key word which actually captures the full form of the acronym SUHAKAM but in English language (i.e. The Human Rights Commission of Malaysia). But an analysis of the concordance lines reveals some interesting findings as exhibited in Table 4 below.

TABLE 4. Selected concordance lines of news stories about SUHAKAM

\begin{tabular}{ll}
\hline 1 & akam probes claim orang asli workers exploited SUHAKAM has expressed concern over the alleged exploi \\
2 & hakam laments plans to amend Act KUALA LUMPUR: Suhakam is disappointed that the Government is procee \\
3 & ang asli in Pos Simpor. 19 Jan 2019 | 12:41 PM Suhakam lauds federal govt's move to sue Kelantan ove \\
4 & ed in Penampang, Sabah. 25 Aug 2011 | 12:00 AM Suhakam laments plans to amend Act KUALA LUMPUR: Suha \\
5 & otect their land rights. 20 Jan 2019 | 7:00 AM Suhakam welcomes move to protect orang asli rights KU \\
6 & MPUR: The Human Rights Commission of Malaysia (Suhakam) has welcomed the federal government's move t \\
7 & JAYA: The Human Rights Commission of Malaysia (Suhakam) is troubled by recent reports of deaths of o \\
8 & director Zahari Ismail. 24 Jan 2017 | 5:46 PM Suhakam denounces demolition of orang asli blockades \\
9 & JAYA: The Human Rights Commission of Malaysia (Suhakam) has condemned the Kelantan Forestry Departme \\
10 & on their ancestral land. 13 Jan 2017 | 5:59 PM Suhakam to probe Johor's alleged Orang Asli land inva \\
11 & ed to the Human Rights Commission of Malaysia (Suhakam) to conduct an enquiry into the Kelantan gove \\
12 & MPUR: The Human Rights Commission of Malaysia (Suhakam) Tuesday urged Kelantan's PAS-led government \\
13 & eged land encroachment. 31 Jan 2012 | 12:00 AM Suhakam urges Kelantan to speedily resolve orang asli \\
14 & UR: An Orang Asli NGO has sent a memorandum to Suhakam to protest against alleged "aggression" by po
\end{tabular}

From table 4, we have observed a pattern as shown in line 1 until line 9 where SUHAKAM is viewed as 'expressing' its feelings/emotions towards a certain event or a certain action especially in relation to the government's and state government's engagement/action (lines 2 [disappointed], 6 [welcomed], and 9 [condemned]). SUHAKAM is represented in the news stories as a body which has the power to push or influence the action of a state's government as shown in line 10 until line 14 where they urge / probe Johor's and Kelantan's state government. In line 9, we have noticed another important entity which appears as a part 
of our key word: Kelantan Forestry department. Subsequently, this brings us to the examination of the key word forestry.

We discovered that some collocates of the key words forestry and department are almost the same and due to this, the discussions of these key words are presented concurrently. All 11 collocates of forestry and 14 collocates of department are presented in Table 5 below. The frequency of the collocates of the key words in Table 5 are written in brackets.

TABLE 5. Collocates of the key word forestry and department

\begin{tabular}{lll}
\hline \multicolumn{1}{c}{ Categories } & Collocates (forestry) & Collocates (department) \\
\hline $\begin{array}{l}\text { Action/verb } \\
\text { People }\end{array}$ & moved (4), operation (5) & review (4), moved (4), \\
& officers (9), police (8), & officers (7), director (15), \\
director (4), & general (5), Dr (4) \\
Government or part of & department (32), state & Parks (5), JHEOA (7), affairs \\
government agencies & $(12)$, dept (5) & (15), JAKOA (14), national (5), \\
& & forestry (32), *prime (6), \\
& & *minister (4) \\
Place & Petaling (4), Jaya (4), & N/A \\
& Kelantan (19) & \\
\hline
\end{tabular}

In Table 5, we have spotted several interesting collocates of forestry such as police and officers. The term forestry, as part of Forestry Department has a role in doing operations and the context of these operations were examined using concordances. Most of the times, the key word forestry appears in news report about one particular incident which happened in Gua Musang where the Orang Asli there were "fighting off the Kelantan government and forestry department to protect their ancestral land" (The Star, 25 January 2017). The incident, which was related to a logging event and blockade, involved the police, and were frequently reported in the news stories from September 2016 until the end of 2017. All instances related to this incident are indicated by the word logging which amounts to 79 instances with $58 \%$ or 46 instances referring to the incident in Gua Musang. The amount of coverage and attention given to this sensitive issue at the time has led to the authorities related to this incident to be cited as some of the most significant positive key words i.e. SUHAKAM, forestry and department. This is implicitly apprehended since Orang Asli usually get "press coverage merely because what took place satisfied the requirement of "bad or negative" news"(Mustafa, 1994, p. 206). Textual evidence of these occurrences in the data are shown in Table 6 below.

TABLE 6. Selected concordance lines of news stories about the Gua Musang incident

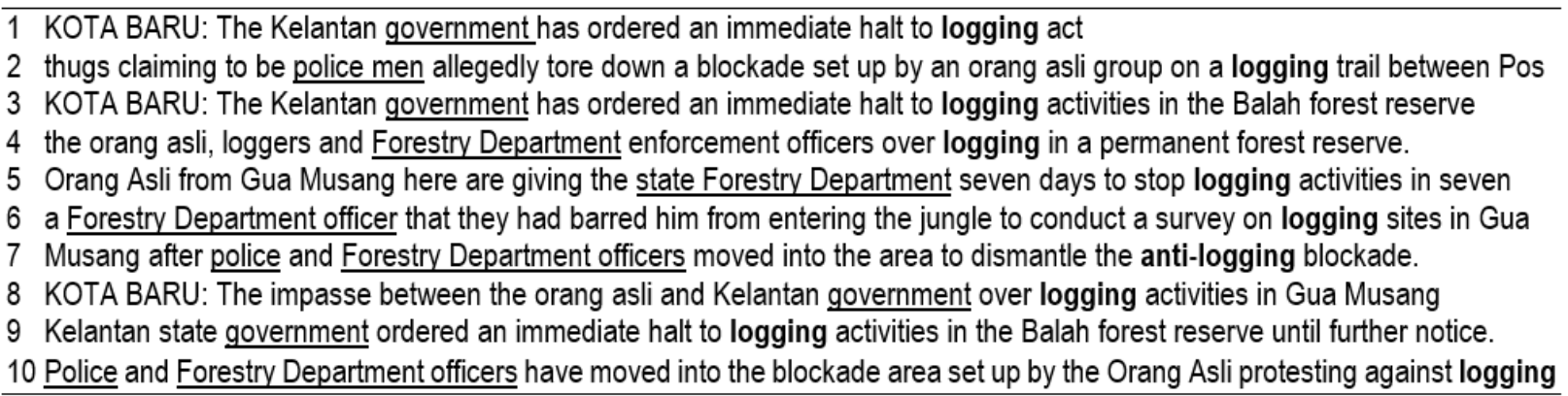

The collocates in the last category - government or part of government agencies - in Table 5 are rather anticipated and predictable. We have identified from our examination of concordances that out of 122 instances of department, 36 instances refer to JAKOA or previously known as Jabatan Hal Ehwal Orang Asli i.e. JHEOA (30\%), while 32 instances (or $26 \%$ ) refer to the Forestry department, and the rest are a mixture of other government agencies 
such as the Prime Minister's Department, Health Department, Road Transport Department and Wildlife and National Park Department. By looking at the number of frequencies, we can say that the JAKOA and Forestry departments are represented in the news stories as the two most prominent governmental agencies directly involved with matters related to the Orang Asli.

What is interesting though is the category of people or part of a title. This category depicts that these departments are being projected and reported through the voices of the director general of the departments which is sometimes identified with their title, for example: Dr. Hasan Abdul Rahman (Pahang Health Department Director), and Dr. Mohd Puad Zarkashi (Deputy Education Minister). Voices of these people are projected as authoritative responses and powerful directives when issues or matters related to Orang Asli transpired. Examples are shown in the excerpt below:

Lead.: Terengganu Health Department Director Dr Mohammad Omar said the Orang Asli children of Kampung Sungai Berua have been diagnosed with having unbalanced diet. He said the health department will be looking into this issue and will provide proper nutrition for the children.

(21 September 2016)

The excerpt shows that the director, as a person with authority, gives a reliable fact about the current condition of the Orang Asli children at the time. Being in such position allows him to also announce his directives to resolve the problem i.e. "the health department...will provide proper nutrition". Many of such directives are given by different representatives from the departments and are usually reported as hard news i.e. news stories that are considered as the main story, generally revolving around important events or incidents (Feez et al., 2010).

The only mention of an Orang Asli representative in the position of a director is Dr Bah Piyan Tan which is reported as "the first from his community to head government department" (The Star, 10 October 2014). More information gathered from the body of the news stories reveals that he was appointed as the Perak Fisheries Department director. His name has appeared in two news stories, with the other one reported on 14 August 2006 when Dr. Bah was reported to receive his $\mathrm{PhD}$ degree. These two news stories however, are categorised as human interest news which function to inspire and motivate the readers especially the Orang Asli (about human interest news see Feez et al., 2010 ). The actor in these two stories was not given any voice in terms of his reactions or actions regarding issues related to Orang Asli, except for inspiring the community's educational development.

Having scrutinised the three key words, SUHAKAM, forestry and department, we could deduce that the voices of authority come from different sources other than the Orang Asli themselves. Sympathisers of Orang Asli like SUHAKAM, to a certain extent are included in important key issues (e.g. doing a probe) but many times, they are merely expressing the feelings of discontent or rejection toward any mistreatment of Orang Asli. At least that is how SUHAKAM is being portrayed in our data set. The final say is always in the hand of the governmental departments and their representatives. And it is important to note here that all this information about authoritative directives and people issuing them are represented in either the headlines or lead paragraphs - those parts of news stories that serve to attract readers, and they contain the most crucial information.

\section{STATE \& GOVERNMENT}

In this section, we concurrently discuss the findings on the key words state and government as they are very closely related in the sense that both are considered the authority with powers, which are in charge of exclusive (e.g. religion, land) and shared scopes. The total number of 
all seven key words is 650 instances while the number of instances of these two key words, state and government, are 382 which actually amount to $59 \%$ of all instances in the authority category. The collocational analysis for the key words state yields 13 collocates and government yields 17 significant collocates. These are shown in Table 7 below:

TABLE 7. Collocates of the key word state and government

\begin{tabular}{|c|c|c|}
\hline & Collocates (state) & Collocates (government) \\
\hline Action/verb & $\begin{array}{l}\text { recognise (5), seeking (4), action } \\
(4), \text { protect }(4)\end{array}$ & $\begin{array}{l}\text { Urging (4), approved (4), recognise } \\
\text { (5), ordered (4), *led (7), *plans (4), } \\
\text { gazetted (4), allocated (10), look (4), } \\
\text { appeal (5), protect (5), take (4) }\end{array}$ \\
\hline Adjective & N/A & Immediate (4) \\
\hline Government extensions & $\begin{array}{l}\text { governments }(6) \text {, govt ( } 4) \text {, federal } \\
(7) \text {, forestry (12) }\end{array}$ & Agencies (7) \\
\hline $\begin{array}{l}\text { (Part of) political party's } \\
\text { name }\end{array}$ & N/A & Pakatan (4), Pas (8) \\
\hline People & director (4) & N/A \\
\hline Place & $\begin{array}{l}\text { Galas (4), Park (7), Royal (5), } \\
\text { Belum (5) }\end{array}$ & Schools (4) \\
\hline
\end{tabular}

Table 7 shows that excerpts for adjective and people category, the collocates of state and government appear in all of the other categories. With regard to the place category, Galas which is a place in Gua Musang, Kelantan, was frequently mentioned due to the Galas byelection that took place in 2018. The rest of the words in place category, refers to Perak's Royal Belum State Park where reports about the death of Orang Asli made the news in November 2015. In this example, the word state is part of a proper noun. Different words that occupy the categories for the two key words inform us the represented role and authority carried out by the state and by the (state or federal) government.

Table 7 also shows the type of actions which the government are engaged in with regard to the issue of Orang Asli. Several words stand out in the action / verb category of the key word government such as ordered and gazetted. The word gazetted for example is related to one of the most prominent issues involving the Orang Asli and the government which is land entitlement. In the OA corpus, the word gazette appears 14 times while the word gazetted appears 16 times. For example: The Perak government has gazetted 2,959.85ha of Orang Asli land. This example shows a straightforward instance of how the action of gazetting land is done by the government. In the excerpts below, it is observed that both the state government and the federal government exercise their upper hands in protecting the interests of the Orang Asli on land matters.

Lead para.: The Selangor Government will make sure that all land belonging to the orang asli in the state is gazetted and the grant issued to them, Mentri Besar Tan Sri Khalid Ibrahim said.

Lead para.: Rural and Regional Development Minister Datuk Seri Mohd Shafie Apdal says the Ministry is engaging the Orang Asli and the state governments to map out better land protection for the community.

16 Nov 2011

On the one hand, it is crystal clear that the government works hard to protect the interests of the Orang Asli communities in the country. However, it can also be seen that the opposite has taken place, as all decisions are undertaken by an authority other than the Orang Asli. As seen in the excerpt below, again the government has exercised its power on land matters, an issue that has long been debated. 
Headline: 'Customary land' term not recognised, says MB

Lead para.: The state government does not recognise the term "customary land" as defined by the Orang Asli, said Mentri Besar Datuk Seri Adnan Yaakob.

19 May 2016

Customary land is sacred to the Orang Asli. By using negation (does not recognise), the government is denying their ancestral rights, as seen in the excerpt above. As we can also see in the excerpt, the term recognise which is one of the significant collocates for the word government also appears in it. In addition, despite the order given by the High Court in favour of the Orang Asli, the Kelantan state government has decided to appeal against it, an exhibition of power over the Orang Asli.

Headline: State govt to appeal High Court ruling

Lead para.: The Kelantan Government is appealing against a High Court order to declare 9361.5ha of land in Pos Belatim, Gua Musang, as orang asli customary land.

28 Apr 2017

Moving beyond the collocations and key words, we also examined the action and reaction of Orang Asli by looking at the data with particular focus on land titles and dispute. The only action performed by the OA or their leaders is "to hope" and it is once more mainly related to land, particularly their ancestral land. Even though they were the victims, the Orang Asli still could not demand justice to be served, as seen in the excerpt below. Instead, they continue "to hope".

Headline: Orang Asli hope to resettle in ancestral land

Lead.: The Orang Asli of Kampung Sunggala near Port Dickson in Negri Sembilan who were forced to leave their homes during the 12-year Emergency from 1948, are appealing to the state government to let them resettle in their ancestral land nearby. 25 Mar 2010

Another action performed by the Orang Asli is "to plead" and this further displays the kind of power that the authority has over matters related to the Orang Asli. In this case, the Orang Asli had to plead to the state government of Perak to save their ancestral land from being developed. Even though the ancestral land belongs to the Orang Asli communities, they could not protect it and had to ask for help from the state government which indicates that an interference from the 'authority' is needed. This can be observed in the excerpt below.

Headline: Legal tussle over Orang Asli land

Lead.: ORANG Asli from Kampung Kuala Senta in Bidor are once again pleading with the Perak government to save their ancestral land from development.

11 Nov 2014

Despite the massive media coverage of notable incidents like the one on the Gua Musang incident mentioned earlier, there is hardly any report about statements by Orang Asli representatives which appear in the headlines and lead paragraphs. We argue that the presence or absence of the Orang Asli representatives especially in headlines is important because the headlines are frequently read (almost five time more) compared to the body of the article (Isani, 2011). In other words, the positioning of the terms related to Orang Asli and their leaders affects their (represented) presence in the mainstream media.

Based on our findings, we conclude that the government is indeed the bigger entity that has definite power over the Orang Asli issues in the country, which includes both the federal government and the state government. The upper hand exercised by the government exhibits both sides of the coins, either the decision made is biased - either for or against the Orang Asli. Glorification and prominence of government's power is not entirely wrong, but as far as the representation in the news goes, it is not the kind of depiction that can empower the Orang Asli community in the long run. 


\section{CONCLUSION}

This study focused on the portrayals of Orang Asli especially how authoritative voices are represented in a Malaysian English language newspaper which we argue has not been thoroughly examined by previous Malaysian studies, but an area which has been analysed by Western studies (e.g. Mesikämmen, 2016). First, we identified the strongest indication of bias is the sheer amount of coverage about authorities other than the Orang Asli leader i.e. Tok Batin (only 19 instances out of 650 instances of authorities in our data. i.e. 3\%). Second, we found consistent stereotypical narrative about Tok Batin where he is represented as emotional (e.g. heart aches) and is placed at the receiving end of things (e.g. salary, allowance). These kind of narratives about Tok Batin are consistently portrayed from 2009 to early 2019. Such narratives are quite different from the depictions of all the other authoritative figures in the authority category (e.g. government, JAKOA). We found multiple times that, the voices being represented, and the decisions being recorded are from the federal or state government and JAKOA. Many headlines and lead paragraphs are about resources, like customary land, and other problems or issues concerning Orang Asli community. This finding is in line with previous study that cited customary land rights as one of the most pertinent issue (Loh, 2011).

As we mentioned before, different methodologies were adopted by past studies of media portrayal of Orang Asli such as content analysis and critical discourse analysis. We argued earlier that by using corpus-assisted critical discourse analysis, we might be able to look further in the use of language in the Orang Asli news discourse. When we compare our findings with previous studies that used CDA, we found that generally some of our findings still arrive at the same discoveries i.e. that the Orang Asli portrayals in the media have not changed much, just as reported in earlier studies. We found instances where the findings are similar in nature in terms of the presence of action verbs or verbs indicating volition (e.g. will be, wil set up, wants) when examining government agencies like JAKOA (see Marlina Jamal \& Shakila Abdul Manan, 2016). This persistent representation actually alludes to a greater issue of media/discourse representations of minority groups in the country and the power of the state. The representation of marginalised Orang Asli remains integral in one of the main news media outlets. However, what was not inherently found in the other studies is that how OA authorities are also depicted as emotional (e.g. heart ache). By using corpus-assisted critical discourse analysis, we were able to scrutinise further in the use of language particularly the type of nouns and verbs used in narrating news stories about Orang Asli by using corpus methods. We found verbs that literally spelled out the kind of power the government authority wields when talking about OA issue (e.g. government is the one in power to: recognise, protect, urge, order, approve, gazette). Such intense words glorify the power and authority of state and government over the OA communities and authorities.

The over representations of authorities and their actions foreshadow the leaders of Orang Asli and their decisions, and consequently muted their voice within the mainstream news media. This is consistent with a research about native Australian where a research found " $[\mathrm{t}] \mathrm{he}$ events that made news were often linked to government announcements, and actors most commonly positioned as agents were government representatives"(Mesikämmen, 2016, p. 13). Indeed, in the Malaysian news narratives, the authoritative figures who are usually quoted and reported in the news associated with Orang Asli matters are the director generals of different governmental departments (e.g. JAKOA, State Forestry Departments, Health Departments). Ultimately, the decision of whether to include or exclude the Orang Asli's voices in important positions such as headlines or lead paragraphs is in the hands of the editors and newsmakers.

The media play a significant role in strengthening and reinforcing an enhanced presence of the Orang Asli, their important agendas and viewpoints in public discussions. Reporters, journalists and the editorial team, have the 'privilege' to either allow or prevent the more 
positive portrayals of Orang Asli. It is their role to decide whether to deny or allow the presence of voice of the minority, like the Orang Asli, to be included in the mainstream media discourse (Carvalho, 2008). On that note, allowing such biased ideological construction to persist in the mainstream media may eventually corrode any pride and power associated with our native people, the Orang Asli.

\section{REFERENCES}

Alagappar, P. N., David, M. K., \& Ramayan, S. K. (2010). Representation of the Orang Asli Community in the Media Agenda-Setting theory Research questions. 3, 90-107.

Baker, P., Gabrielatos, C., KhosraviNik, M., Krzyzanowski, M., McEnery, T., \& Wodak, R. (2008). A Useful Methodological Synergy? Combining Critical Discourse Analysis and Corpus Linguistics to Examine Discourses of Refugees and Asylum Seekers in the UK Press. Discourse \& Society, 19(3), 273-306.

Bednarek, M. (2014). The Television Title Sequence: A Visual Analysis of Flight of The Conchords. In E. Djonov \& S. Zhao (Eds.), From Multimodal to Critical Multimodal Studies through Popular Discourse (pp. 3654). New York: Routledge.

Bednarek, M., \& Caple, H. (2014). Why Do News Values Matter? Towards a New Methodological Framework for Analysing News Discourse in Critical Discourse Analysis and Beyond. Discourse \& Society, 25(2), 135-158.

Browne, J., Gleeson, D., Adams, K., Atkinson, P., \& Hayes, R. (2018). Coverage of aboriginal and Torres Strait Islander nutrition in major Australian newspapers, 1996-2015. Australian and New Zealand Journal of Public Health, 42(3), 277-283.

Burrows, E. (2004). Bridging our differences: comparing mainstream and Indigenous media cover- age of Corroboree 2000. Australian Journalism Review, 26(1): 175-190.

Carvalho, A. (2008). Media(ted) discourse and society: Rethinking the framework of critical discourse analysis. Journalism Studies, 9(2), 161-177.

Clark, B. (2017). Applied diversity: A normative approach to improving news representations of ethno-cultural minorities based on the Canadian experience. Journal of Applied Journalism \& Media Studies, 6(2), 245267.

Drache, D., Fletcher, F., \& Voss, C. (2016). What the Canadian Public is Being Told About the More than 1200 Missing \& Murdered Indigenous Women and First Nations Issues: A Content and Context Analysis of Major Mainstream Canadian Media, 2014-2015. SSRN Electronic Journal, 1-58.

Duc, D. V. (2013). Language and Ideology in English and Vietnamese Business Hard News Reporting - A Comparative Study. 3L: The Southeast Asian Journal of English Language Studies, 19(2), 1-12.

Fairclough, N. (1995). Critical Discourse Analysis. The Critical Study of Language. London: Longman.

Feez, S., Iedema, R., \& White, P. (2010). Media Literacy. Surry Hills, Australia: New South Wales Department of Education and Training.

Fleras, A. \& Kunz, J.L. (2001). Media and Minorities: Representing Diversity in a Multicultural Canada. Toronto: Thompson Educational Publishing Inc.

Hardt-Mautner, G. (1995). ' Only Connect' : Critical Discourse Analysis and Corpus Linguistics. In UCREL Technical Paper 6. Lancaster: Lancaster University.

Hunston, S. (2002). Corpora in Applied Linguistics. Cambridge: Cambridge Univeristy Press.

Iqbal, A., Danish, M. H., \& Iqbal, F. (2014). Critical Discourse Analysis of Attributive Words Used with the Word Muslim: A Corpus Based Study. International Journal of Linguistics, 6(4), 1-11.

Isani, S. (2011). Of headlines \& headlinese: Towards distinctive linguistic and pragmatic genericity. ASp, (60), 81-102.

Marlina Jamal \& Shakila Abdul Manan (2016). An Ideological Construction of the Indigenous Community: The Orang Asli as Portrayed in The Star Newspaper. Kemanusiaan The Asian Journal of Humanities, 23(2), 39-62.

Loh, C. M. (2011). A Study of Comparison Media Coverage between Mainsteram News Website The Star and Alternative News Website the Malaysia Insider.

Lukac, M. (2011). Down to the Bone : A Corpus-based Critical Discourse Analysis of Pro-eating Disorder Blogs. Jezikoslovlje, 12(2), 187-209.

Marchi, A., \& Taylor, C. (2009). If on a Winter's Night Two Researchers... A Challenge to Assumptions of Soundness of Interpretation. Critical Approaches to Disourse Analysis across Disciplines, 3(1), 1-20.

Martins, I. D. S. (2009). A Police Case: The Representation of Discourses in the Crime News Reports of Two Brazilian Print Newspapers in Light of Corpus Linguistics and Critical Discourse Analysis. Revista Virtual de Estudos Da Linguagem ReVEL, 7(13).

McCallum, K., Waller, L., \& Meadows, M. (2012). Raising the volume: Indigenous voices in news media and 
policy. Media International Australia Incorporating Culture and Policy, (142), 101-111.

Meadows, M. (2001). Voices in the wilderness: Images of aboriginal people in the Australian media. Westport, CT: Greenwood Press.

Mesikämmen, E. (2016). Limited interests, resources, voices: power relations in mainstream news coverage of Indigenous policy in Australia. Media, Culture and Society, 38(5), 721-737.

Mulderrig, J. (2012). The Hegemony of Inclusion: A Corpus-based Critical Discourse Analysis of Deixis in Education Policy. Discourse \& Society, 23(6), 701-728.

Mustafa, K. A. (1994). The Malaysian Press and Representation of Minority Groups. Sojourn: Journal of Social Issues in Southeast Asia, 9(2), 200-212.

Nadhratunnaim, A., \& Surinderpal, K. (2019). Theologising the Discourse of Representation through ' Faith ' and Religion in Football News. 3L: The Southeast Asian Journal of English Language Studies, 25(3), 150162.

Newman, N., Fletcher, R., Kalogeropoulos, A., Levy, D., \& Nielsen, R. K. (2018). Reuters Institute Digital News Report 2018. In Reuters Institute for the Study of Journalism.

Orpin, D. (2005). Corpus Linguistics and Critical Discourse Analysis Examining the Ideology of Sleaze. International Journal of Corpus Linguistics, 10(1), 37-61.

Pierro, R., Barrera, J., Blackstock, C., Harding, R., McCue, D., \& Metawabin, M. (2013). Buried Voices: Media Coverage of Aboriginal Issues in Ontario Media Monitoring Report: 2010-2013. 2010-2013. Retrieved from www.jhr.ca

Prentice, S., \& Hardie, A. (2009). Empowerment and Disempowerment in the Glencairn Uprising: A Corpusbased Critical Analysis of Early Modern English News Discourse. Journal of Historical Pragmatics, 10(1), 23-55.

Renugah, R., \& Tan, B. H. (2015). Application of Critical Discourse Analysis in Media Discourse Studies. 3L: The Southeast Asian Journal of English Language Studies, 21(2), 57-68.

Richardson, J. E. (2007). Analysing Newspapers : An Approach from Critical Discourse Analysis. New York: Palgrave Macmillan.

Salama, A. H. Y. (2011). Ideological Collocation and the Recontexualization of Wahhabi-Saudi Islam post-9/11: A Synergy of Corpus Linguistics and Critical Discourse Analysis. Discourse \& Society, 22(3), 315-342.

Scott, M. (2014a). WordSmith Tools (Version 6.0) [Computer Application]. Liverpool: Lexcial Analysis Software Ltd.

Scott, M. (2014b). WordSmith Tools Manual 6.0. Liverpool: Lexcial Analysis Software Ltd.

$\mathrm{Su}, \mathrm{H}$. T. (2017). An Agenda-setting Study of National Day Coverage in State and National Newspapers. $3 L$ : The Southeast Asian Journal of English Language Studies, 23(4), 41-55.

Tarmiji, M., Masami, F., \& Norhasimah, I. (2013). Orang Asli in Peninsular Malaysia: Population, Spatial Distribution and Socio-Economic Condition. J. Ritsumeikan Soc. Sci. Humanit, 6, 75-115.

Thaniago, R. (2017). Disciplining Tionghoa. Lund Univerisity.

van Dijk, T. A. (1993). Structures of News in the Press. In T. A. van Dijk (Ed.), Discourse and Communication (pp. 69-93). Berlin: De Gruyter.

Widdowson, H. G. (2004). Text, Context, Pretext. Critical Issues in Critical Discourse Analysis. Oxford: Blackwell.

Wodak, R., \& Meyer, M. (2009). Critical Discourse Analysis: History, Agenda, Theory, and Methodology. In R. Wodak \& M. Meyer (Eds.), Methods for Critical Discourse Analysis (2nd ed., pp. 1-33). London: SAGE. 